\title{
PENGARUH MANAJEMEN MODAL KERJA TERHADAP PROFITABILITAS BANK PERKREDITAN RAKYAT (BPR) DI MADIUN, MAGETAN, NGAWI DAN PONOROGO
}

\author{
Juli Murwani \\ IKIP PGRI Madiun \\ jmurwani@yahoo.co.id \\ Oerip Pujiati \\ IKIP PGRI Madiun
}

\begin{abstract}
ABSTRAK
Penelitan bertujuan untuk menguji pengaruh manajemen modal kerja (working capital) terhadap profitabilitas Bank Perkreditan Rakyat (BPR) yang ada di Kabupaten-Kota Madiun, Magetan, Ngawi dan Ponorogo. Bank Perkreditan Rakyat (BPR) memiliki peran yang penting dalam menggerakan roda perekonomian di daerah. Sebagai lembaga keuangan yang ada di daerah dan bersentuhan langsung dengan masyarakat menengah ke bawah, penelitian tentang profitabilitas Bank Perkreditan Rakyat (BPR) penting dilakukan untuk menilai kinerja Bank Perkreditan Rakyat. Tipe BPR yang menjadi objek penelitian adalah BPR konvensional. Data dalam penelitian ini diperoleh dari laporan triwulanan Bank Perkreditan Rakyat yang dipublikasikan melalui website Bank Indonesia tahun 2012-2014. Data diambil dengan menggunakan metoda purposive sampling. Data dianalisis dengan menggunakan regresi linier berganda. Hasil penelitian ini menunjukan bahwa : 1) rasio manajemen modal kerja berupa rasio keuangan aktiva lancar/total aktiva berpengaruh negatif terhadap profitabilitas BPR. 2) Rasio manajemen modal kerja berupa rasio keuangan hutang lancar/total aktiva tidak berpengaruh terhadap profitabilitas BPR. 3) Rasio manajemen modal kerja berupa rasio keuangan current ratio berpengaruh negatif terhadap profitabilitas BPR. 4) Rasio manajemen modal kerja berupa rasio keuangan rasio kas berpengaruh negatif terhadap profitabilitas BPR. 5) Rasio manajemen modal kerja berupa rasio keuangan rasio hutang berpengaruh negatif terhadap profitabilitas BPR.

Kata kunci : Bank Perkreditan Rakyat, Modal Kerja, Profitabilitas, Kinerja
\end{abstract}

\section{PENDAHULUAN}

Bank adalah lembaga keuangan yang usaha pokoknya adalah menghimpun dana dan menyalurkan kembali dana tersebut ke masyarakat dalam bentuk kredit serta memberikan jasa-jasa dalam lalu lintas pembayaran dan peredaran uang (Kalesaran, 2013). Di dalam Pasal 1 Undang-Undang No. 10 tahun 1998 bank merupakan badan usaha yang menghimpun dana dari masyarakat dalam bentuk simpanan dan menyalurkannya kepada masyarakat dalam bentuk kredit dan/atau bentuk lainnya dalam rangka meningkatkan taraf hidup masyarakat banyak (Sukma, 2011), sedankan Bank Perkreditan Rakyat (BPR) merupakan salah satu jenis bank yang kegiatan utamanya adalah menghimpun dana dan menyalurkan kredit kepada masyarakat. Kredit sebagai pendapatan utama bagi BPR diharapkan dapat menjaga kualitas kreditnya dengan baik (Maharani dan Ramantha, 2014).

Menurut Islamiyah (2010), Bank Perkreditan Rakyat menerima simpanan hanya dalam bentuk deposito berjangka, tabungan, dan bentuk lainnya yang dipersamakan dengan itu. Pada mulanya tugas pokok BPR diarahkan untuk menunjang pertumbuhan dan modernisasi ekonomi perdesaan serta mengurangi praktek-praktek ijon dan para pelepas uang (rentenir). Namun demikian, peran Bank Perkreditan Rakyat saat ini semakin penting sebagai penyedia sumber pendanaan dan penggerak roda perekonomian di daerah. Handan dan Wijaya (2006) 
menjelaskan bahwa tugas pokok BPR adalah mengembangkan perekonomian rakyat didaerah, terutama pedesaan, bagi golongan ekonomi lemah, dengan membantu pembiayaan, dalam rangka meningkatkan taraf hidup rakyat.

Septianto Dan Widiharih (2010) menjelaskan bahwa Bank Perkreditan Rakyat (BPR) dituntut untuk dapat bertahan menghadapi krisis ekonomi global yang terjadi saat ini karena BPR berperan penting dalam memberikan pembiayaan pada sektor UMKM (Usaha Mikro, Kecil dan Menengah) di seluruh daerah. BPR memiliki prosedur pelayanan yang sederhana, proses yang cepat dan skema kredit yang lebih mudah disesuaikan serta lokasi tersebar di seluruh daerah baik perkotaan maupun pedesaan dibandingkan dengan bank umum. Bank umum juga berperan dalam memberikan pembiayaan tetapi dengan bentuk kredit yang baku serta lokasinya yang hanya ada di perkotaan. Mengingat begitu pentingnya peranan Bank Perkreditan Rakyat (BPR) bagi penyediaan pendanaan UMKM di daerah, maka penelitian tentang evaluasi kinerja BPR penting dilakukan untuk tujuan penilaian keberlajutan operasi BPR dan keamanan dana nasabah.

Salah satu cara untuk menilai kinerja Bank Perkreditan Rakyat (BPR) adalah dengan melihat profitabilitasnya. Profitabilitas sebuah perusahaan adalah kemampuan perusahaan dalam menghasilkan laba. Laba yang didapatkan oleh sebuah BPR akan berdampak terhadap kemampuan keuangan internal. Tentunya, BPR yang profitabel akan lebih aman dari sisi keuangan, memiliki kemampuan bertahan dari krisis keuangan, jauh dari risiko kebangkrutan dan lebih bisa berkembang secara bisnis.

Dari sisi nasabah, BPR yang profitabel merupakan jaminan akan keamanan dana yang disimpan pada BPR sekaligus jaminan bahwa BPR tersebut mampu menyediakan dana yang cukup ketika nasabah akan mengajukan kredit. Salah satu faktor yang mempengaruhi kamampuan perusahaan dalam menghasilkan laba adalah manajemen modal kerja (working capital management). Falope dan Aljilore (2009) menyebutkan bahwa manajemen modal kerja adalah tata cara perusahaan dalam melakukan pengelolaan investasi pada aktiva jangka pendek perusahaan. Jumlah yang diinvestasikan perusahaan dalam modal kerja harus digunakan dengan efisien, tujuannya menjaga keseimbangan antara likuiditas dan profitabilitas untuk menjalankan aktivitas operasional bisnis perusahaan sehari-hari.

Manajemen modal kerja juga menjadi hal yang penting dalam kegiatan operasional BPR. Ketersediaan modal kerja yang optimal akan pada kegiatan kegiatan BPR, yaitu kegiatan operasional yang lancar, kondisi likuditas yang terjaga dengan baik, perputaran uang tunai yang cepat dan peningkatan pendapatan BPR. Pada akhirnya, manajemen modal kerja yang optimal akan mampu meningkatkan laba BPR dan berdampak baik bagi kondisi kesehatan keuangan BPR dan nilai BPR di masyarakat.

Penelitian ini akan dilakukan pada BPR Konvensional yang ada di Kabupaten dan Kota Madiun, Kabupaten Magetan, Kabupaten Ngawi serta Kabupaten Ponorogo Jawa Timur. Pengamatan awal menunjukan bahwa di wilayah Kabupaten dan Kota Madiun, Kabupaten Magetan. Kabupaten Ngawi dan Kabupaten Ponorogo terdapat 23 Bank Perkreditan Rakyat (BPR) dengan bertipe BPR Konvensional. Jumlah tersebut menunjukan bahwa peran BPR di wilayah ini cukup signifikan dalam menopang kebutuhan pendanaan UMKM serta masyarakat umum. Berdasar hal tersebut penelitian tentang profitabilitas sebagai upaya penilaian kinerja BPR di Madiun, Magetan, Ngawi dan Ponorogo penting dan menarik untuk dilakukan. 


\section{TINJAUAN PUSTAKA DAN PENGEMBANGAN HIPOTESIS}

\section{A. Bank Perkreditan Rakyat}

Herri et al. (2008) menyatakan bahwa Bank Perkreditan Rakyat (BPR) adalah salah satu bentuk lembaga keuangan mikro di Indonesia yang telah memiliki akar dalam sosial ekonomi masyarakat pedesaan Indonesia. Menurut Undang Undang Republik Indonesia No. 7 tahun 1992 tentang Perbankan, sebagaimana telah diubah dengan Undang-Undang No. 10 tahun 1998, BPR adalah bank yang melaksanakan kegiatan usaha secara konvensional atau berdasarkan Prinsip Syariah yang dalam kegiatannya tidak memberikan jasa dalam lalu lintas pembayaran. Usaha BPR meliputi, menghimpun dana dari masyarakat dalam bentuk simpanan berupa deposito berjangka, tabungan, dan atau bentuk lainnya yang dipersamakan dengan itu; memberikan kredit; menyediakan pembinaan dan penempatan dana berdasarkan Prinsip Syariah sesuai dengan ketentuan yang ditetapkan oleh Bank Indonesia; menempatkan dananya dalam bentuk Sertifikat Bank Indonesia, deposito berjangka, sertifikat deposito dan tabungan pada bank lain.

Bank Perkreditan Rakyat (BPR) merupakan lembaga keuangan yang dibentuk untuk melayani kebutuhan pelayanan jasa-jasa perbankan bagi masyarakat ekonomi lemah, terutama usaha kecil di Indonesia. Peran BPR kepada usaha kecil dianggap penting bagi peningkatan pembiayaan usaha mikro dan kecil karena selama ini usaha kecil sebagai sektor yang berperan penting dalam perekonomian Indonesia memerlukan suntikan modal dari pihak luar. Peran usaha kecil yang besar ditunjukkan oleh kontribusinya terhadap produksi nasional, jumlah unit usaha dan pengusaha, serta penyerapan tenaga kerja. Meskipun demikian, perkembangan usaha kecil di Indonesia masih menghadapi berbagai kendala, terutama dalam hal pemenuhan modal usaha dari lembaga keuangan formal seperti bank (Azrian et al., 2008).

Kumara (2009) menjelaskan bahwa dalam pelaksanaan kegiatan usahanya BPR dapat menjalankan usahanya secara konvensional atau berdasarkan prinsip syariah. Kegiatan usaha yang diperkenankan dilakukan oleh BPR sangat terbatas dibandingkan dengan bank umum, yaitu hanya meliputi penghimpunan dana dari masyarakat dalam bentuk simpanan berupa deposito berjangka, tabungan atau bentuk lainnya yang dipersamakan dengan itu, memberikan kredit serta menempatkan dana dalam bentuk Sertifikat Bank Indonesia (SBI), deposito berjangka, sertifikat deposito, dan tabungan pada bank lain. BPR tidak diperkenankan menerima simpanan berupa giro dan ikut serta dalam lalu lintas pembayaran serta melakukan kegiatan usaha selain yang diperkenankan. Kegiatan usaha yang dilakukan BPR salah satunya adalah memberikan kredit untuk Usaha Mikro, Kecil dan Menengah (UMKM).

Handan dan Wijaya (2006) menjelaskan bahwa dalam melaksanakan fungsinya, BPR melakukan beberapa kegiatan-kegiatan seperti menghimpun dana jangka pendek, menengah, dalam bentuk Tabungan dan Deposito; pembinaan dan pembiayaan dunia usaha, khususnya membantu pengembangan usaha golongan ekonomi lemah; memobilisasikan dana masyarakat sebagai sumber pembangunan di daerah; memberikan pembiayaan jangka pendek, menengah dan panjang kepada perusahaan-perusahaan perorangan untuk keperluan pembangunan; melakukan kerja sama sesama bank dan Lembaga Keuangan dan menjalankan usaha-usaha perbankan lainnya, sepanjang tidak bertentangan dengan peraturan dan Undang-Undang yang berlaku. 
Bank Perkreditan Rakyat (BPR) memiliki peran yang sangat besar dalam menggerakan roda perekonomian terutama bagi masyarakat menengah ke bawah yang ada di daerah. Bank Perkreditan Rakyat (BPR) menjadi alternatif sumber pendanaan bagi masyarakat daerah terutama di pedesaan. Melihat peran yang strategis tersebut, maka penelitian tentang kinerja BPR perlu untuk dilakukan sebagai upaya menjaga tingkat kesehatan dan keberlangsungan operasional BPR. Salah satu faktor yang diduga berpengaruh terhadap kinerja BPR adalah manajemen modal kerja. Manajemen modal kerja BPR akan terkait dengan kecukupan modal kerja, aspek likuditas dan kesehatan keuangan BPR.

\section{B. Manajemen Modal Kerja dan Profitabilitas}

Sur dan Chakraborty (2011) menyatakan bahwa modal kerja (working capital) adalah uang yang digunakan untuk menjalankan bisnis perusahaan sehari-hari. Tujuan utama dari manajemen working capital adalah memberikan dukungan yang memadai terhadap jalannya bisnis perusahaan. Salah satu faktor yang terkait dengan manajemen modal kerja BPR adalah aspek kecukupan modal. Rasio Kecukupan modal mencerminkan modal sendiri perusahaan, semakin besar nilai rasio ini maka akan semakin besar kesempatan bank dalam menghasilkan laba, karena dengan modal yang besar manajemen bank sangat leluasa dalam menempatkan dananya ke dalam aktivitas investasi yang menguntungkan (Sukma, 2013).

Qayyum et al. (2010) menjelaskan bahwa ada dua pendapat yang menjelaskan hubungan antara manajemen modal kerja dan profitabilitas. Pertama, perusahaan dengan kebijakan yang agresif akan mengurangi proposi aktiva lancar dalam total aktiva perusahaan dengan tujuan mengurangi modal kerja perusahaan dan meningkatkan profitabilitas perusahaan. Pandangan ini percaya bahwa perusahaan dapat meningkatkan profitabilitas dengan cara mengurangi komponen modal kerja. Kedua, perusahaan dengan tipe yang konservatif akan menghasilkan laba yang besar. Perusahaan yang melakukan investasi tinggi pada modal kerja akan dapat meningkatkan profitabilitas. Perusahaan yang menjaga persediaan dalam jumlah yang tinggi, akan dapat mengurangi biaya yang disebabkan gangguan saat proses produksi, mengurangi supply cost, melindungi produk dari fruktuasi harga dan resiko kehilangan bisnis ketika terjadi kelangkaan barang. Pandangan ini menilai bahwa perusahaan yang memiliki working capital yang besar akan memiki profitabilitas yang besar pula.

Falope dan Aljilore (2009) menjelaskan bahwa terdapat trade off antara profitabilitas dan likuiditas dalam manajemen modal kerja perusahaan. Perusahaan bisa saja memberikan konsumen kredit secara lebih liberal, pada satu sisi penjualan perusahaan akan meningkat yang artinya profitabilitas tinggi namun pada saat yang sama likuiditas perusahaan menjadi menurun. Penelitian Nazir dan Afza (2009) memberikan penjelasan bahwa perusahaan dengan kebijakan keuangan yang agresif justru akan memperoleh laba yang kecil jika dibandingkan dengan perusahaan yang konservatif. Perusahaan yang menerapkan manajemen modal kerja yang agresif mampu mendorong peningkatan nilai perusahaan di pasar namun tidak dapat meningkatkan profitabilitas perusahaan. 
Harahap (2010) menyatakan bahwa likuiditas merupakan suatu hal yang sangat penting bagi bank karena akan berdampak pada profiitabililitas serta business sustainibility and continuity. Hal tersebut tercermin dari peraturan bank Indonesia yang menetapkan likuiditas sebagai salah satu dari delapan risiko yang harus dikelola oleh bank. Pengertian likuiditas dalam dunia perbankan lebih kompleks dibanding dengan dunia bisnis secara umum. Dari sudut aktiva, likuiditas adalah kemampuan untuk mengubah seluruh aset menjadi bentuk tunai (cash), sedangkan dari sudut pasiva, likuiditas adalah kemampuan bank memenuhi kebutuhan dana melalui peningkatan portofolio liabilitas. Secara garis besar manajemen likuiditas terdiri dari dua bagian, yaitu; pertama, memperkirakan kebutuhan dana, yang berasal dari penghimpunan dana (deposit inflow) dan untuk penyaluran dana (fund out flow) dan berbagai komitmen pembiayaan (finance commitments).

Beberapa penelitian sebelumnya terkait dengan manajemen modal kerja memberikan hasil yang tidak konklusif. Sukma (2013) menyatakan bahwa dengan adanya modal yang memadai bank dapat melakukan kegiatan operasionalnya secara lebih efisien melalui pengalokasian dana pada aset produktif yang memberikan keuntungan bagi bank dan risiko yang kecil. Rasio kecukupan modal yang tinggi menunjukkan semakin stabil usaha bank karena adanya kepercayaan masyarakat yang stabil. Rasio kecukupan modal dihubungkan dengan tingkat risiko bank. Semakin kecil risiko suatu bank maka semakin besar keuntungan yang diperoleh bank. Tingginya rasio capital dapat melindungi nasabah, yang dapat meningkatkan kepercayaan masyarakat terhadap bank sehingga profitabilitas dapat meningkat.

Penelitian Dong dan Su (2010) menemukan bahwa periode konversi kas berpengaruh negatif terhadap profitabilitas perusahaan sedangkan log sales, leverage dan rasio aktiva tetap berpengaruh positif terhadap profitabilitas perusahaan. Hasil penelitian Muhamad dan Saad (2010) menunjukkan bahwa current ratio, rasio hutang jangka pendek terhadap total aktiva perusahaan berpengaruh negatif terhadap profitabilitas perusahaan, rasio aktiva lancar terhadap total aktiva berpengaruh positif terhadap profitabilitas dan rasio hutang tidak berpengaruh signifikan terhadap profitabiitas perusahaan.

Dengan masih banyaknya hasil penelitian yang belum konsisten dalam dalam memberikan penjelasan tentang manajemen modal kerja dan profitabilitas perusahaan, maka perlu dilakukan kembali penelitian tentang komponen modal kerja kaitannya dengan profitabilitas perusahaan. Penelitian ini akan menguji komponen modal kerja perusahaan berupa rasio aktiva lancar/total aktiva, rasio hutang lancar/ total aktiva, current ratio, rasio kas, dan raio hutang. Penelitian ini akan dilakukan pada tipe industri jasa keuangan dengan objek penelitian Bank Perkreditan Rakyat (BPR) konvensional yang ada di Kabupaten/ Kota Madiun, Kabupaten Magetan, Kabupaten Ngawi, dan Kabupaten Ponorogo.

\section{Hipotesis Penelitian}

Hipotesis penelitian yang akan diuji dalam penelitian ini teringkas dalam pernyataan hipotesis di bawah ini. 
H1: Manajemen modal kerja berpengaruh terhadap profitabilitas BPR di Madiun, Magetan, Ngawi dan Ponorogo

H1a: Rasio aktiva lancar/total aset berpengaruh terhadap profitabilitas BPR di Madiun, Magetan, Ngawi dan Ponorogo

H1b: Rasio hutang lancar/total aset berpengaruh terhadap profitabilitas BPR di Madiun, Magetan, Ngawi dan Ponorogo

H1c: Current ratio berpengaruh terhadap profitabilitas BPR di Madiun, Magetan, Ngawi dan Ponorogo

H1d: Rasio kas berpengaruh terhadap profitabilitas BPR di Madiun, Magetan, Ngawi dan Ponorogo

H1e: Rasio hutang berpengaruh terhadap profitabilitas BPR di Madiun, Magetan, Ngawi dan Ponorogo

\section{METODE PENELITIAN}

\section{A. Populasi, Sampel dan Data Penelitian}

Populasi dalam penelitian ini adalah seluruh Bank perkreditan Rakyat yang ada di Kabupaten dan Kota Madiun, Kabupuaten Magetan, Kabupaten Ngawi dan Kabupaten Ponorogo Propinsi Jawa Timur. Penelitian ini menggunakan data sekunder dari laporan keuangan triwulanan perioda 2012-2014. Data dalam penelitian ini diambil dengan metode purposive sampling, dengan kriteria:

1) BPR Konvensional.

2) Memiliki kantor pusat di wilayah Kabupaten dan Kota Madiun, Kabupuaten Magetan, Kabupaten Ngawi dan Kabupaten Ponorogo.

3) Menerbitkan laporan keuangan triwulanan di Website Bank Indonesia

4) Memiliki data yang lengkap sesuai dengan kebutuhan peneliti.

Data dalam penelitian ini dianalisis dengan menggunakan regresi linier berganda dengan bantuan software SPSS for Windows 15.0.

\section{B. Definisi Operasional Variabel}

1) Variabel Independen

Variabel independen dalam penelitian ini adalah manajemen modal kerja BPR. Modal kerja BPR dalam penelitian ini diukur dengan beberapa rasio keuangan sebagai berikut:

a. Aktiva Lancar/Total Aktiva

Aktiva lancar/Total Aktiva adalah rasio keuangan yang membandingkan antara aktiva lancar dengan total aktiva perusahaan. Mengacu Pada penelitian Dong dan $\mathrm{Su}$ (2010), rasio ini dinotasikan dengan rumus sebagai berikut:

Aktiva Lancar/ Total Aktiva $=\frac{\text { Aktiva Lancar }}{\text { Total aktiva }}$

b. Hutang Lancar/Total Aktiva

Hutang lancar/Total Aktiva adalah rasio keuangan yang membandingkan antara hutang lancar dengan total aktiva perusahaan. Mengacu Pada penelitian Dong dan $\mathrm{Su}$ (2010), rasio ini dinotasikan dengan rumus sebagai berikut:

Hutang Lancar/ Total Aktiva $=\frac{\text { Hutang Lancar }}{\text { Totalaktiva }}$ 
c. Current Ratio

Current Ratio adalah rasio keuangan yang membandingkan antara aktiva lancar dengan hutang lancar perusahaan. Mengacu pada penelitian Wijaya dan Suswandari (2014) rasio ini dinotasikan dengan rumus sebagai berikut:

d. Rasio Kas

$$
\text { Rasio Kas }=\frac{\text { Kas dan setara kas }}{\text { Total aktiva }}
$$

Rasio Kas adalah rasio keuangan yang membandingakn antara total kas dan setara kas yang dimiliki oleh BPR dengan total aktivanya. Rasio kas mengacu pada penelitian Wijaya dan Suswandari (2014) dinotasikan dengan rumus sebagai berikut:

$$
\text { Rasio Kas }=\frac{\text { Kas dan setara kas }}{\text { Total aktiva }}
$$

e. Rasio Hutang

Rasio hutang merupakan rasio kerungan perusahaan yang membandingkan antara total hutang dengan total aktiva perusahaan. Mengacu pada panelitian Dong dan $\mathrm{Su}$ (2010), rasio hutang dinotasikan dengan rumus sebagai berikut.

$$
\text { Leverage }=\frac{\text { Total hutang }}{\text { Total aktiva }}
$$

2) Variabel Dependen

Variabel dependen dalam penelitian ini adalah profitabilitas BPR. Profitabilitas dapat didefinisikan sebagai kemampuan perusahaan dalam menghasilkan laba. Profitabilitas diproksikan dengan Return on Asset (ROA). Return on asset (ROA) merupakan rasio yang membandingkan antara laba bersih dan total aktiva perusahaan, di notasikan dengan persamaan sebagai berikut.

ROA $=\frac{\text { Laba bersih }}{\text { total aktiva }}$

\section{Uji Statistik Penelitian}

1) Uji Model Penelitian

Hipotesis dalam penelitian ini diuji dengan menggunakan regresi linier berganda sehingga sebelum melakukan uji hipotesis dilakukan pengujian terhadap model regersi berupa uji normalitas data dan uji asumsi klasik. Uji asumsi klasik meliputi uji multikolinieritas, uji autokorelasi dan uji heterokesdastisitas.

2) Uji Hipotesis

Hipotesis dalam penelitian ini diuji dengan regresi linier berganda dengan persamaan regresi sebagai berikut.

$\mathrm{PROF}=\alpha+\beta 1 \mathrm{AL} / \mathrm{TA}+\beta 2 \mathrm{HL} / \mathrm{TA}+\beta 3 \mathrm{CR}+\beta 4 \mathrm{CASH}+\beta 5 \mathrm{DR}+\mathrm{e}$

Keterangan:

PROF = Profitabilitas,

AL/TA $\quad=$ Aktiva lancar/ total aktiva,

HL/TA = hutang lancar/ total aktiva,

$\mathrm{CR}=$ cuuret ratio,

$\mathrm{CASH} \quad=$ rasio kas, 


$$
\begin{array}{ll}
\mathrm{DR} & =\text { rasio hutang, } \\
\beta 1-\beta 5 & =\text { Koefisien Regeresi, } \\
\mathrm{e} & =\text { error } .
\end{array}
$$

Analisis regresi linier berganda meliputi beberapa analisis sebagai berikut.

(a) Koefisien Determinasi $\left(\operatorname{Adj} . R^{2}\right)$

Koefisien determinasi adalah nilai yang menunjukkan seberapa besar variabel independen dapat menjelaskan variasi variabel dependen (Ghozali 2005).

(b) Nilai F

Nilai F regresi merupakan pengujian yang digunakan untuk menguji apakah variabel independen berpengaruh secara bersama-sama atau simultan terhadap variabel dependen (Ghozali 2005). Nilai $F$ dalam penelitian ini menggunakan tingkat signifikansi $5 \%$.

(c) Nilai $\mathrm{t}$

Nilai t regresi merupakan pengujian yang dilakukan untuk mengetahui apakah variabel independen berpengaruh secara signifikan terhadap variabel dependen. Nilai t dalam penelitian ini menggunakan tingkat signifikansi $5 \%$. Variabel independen dikatakan berpengaruh signifikan terhadap variabel dependen apabila nilai sig (p-value) di bawah 5\% (Ghozali 2005).

\section{ANALISIS DATA \\ Statistik Deskriptif}

Berdasar pada kriteria yang telah ditentukan sebelumnya, diperoleh sampel sebanyak 201 Bank Perkreditan Rakyat di Ngawi, Madiun, Magetan dan Ponorogo. Adapun Penjelasan Mengenai Statistik Deskprotif dapat dilihat pada tabel berikut ini

Tabel 1 Statistik Deskriptif

\begin{tabular}{|l|r|r|r|r|r|}
\multicolumn{7}{|c|}{ Descriptive Statistics } \\
\hline ROA & N & Minimum & Maximum & Mean & Std. Deviation \\
ALTA & 201 & .00 & .10 & .0320 & .02062 \\
HLTA & 201 & .01 & .70 & .2066 & .13662 \\
CR & 201 & .02 & .79 & .3458 & .19606 \\
CASH & 201 & .03 & 5.36 & .8931 & .97049 \\
LEV & 201 & .00 & .05 & .0081 & .00826 \\
Valid N (listwise) & 201 & .09 & .95 & .7775 & .15842 \\
\hline
\end{tabular}

\section{Uji Asumsi Klasik}

Model regresi yang digunakan dalam penelitian ini telah lolos uji asumsi klasik, Hasil uji normalitas menunjukkan nilai p sebesar 0,094 sehingga dapat disimpulkan bahwa data dalam penelitian ini telah berdistribusi normal. Hasil uji multikolinieritas menunjukkan bahwa semua nilai VIF di bawah nilai 10 dan nilai tolerance di atas $10 \%$, sehingga dapat disimpulkan bahwa dalam model regersi tidak terjadi masalah multikolinieritas. Hasil uji autokorelasi menunjukkan nilai DW hitung sebesar 1,504 sehingga disimpulkan bahwa tidak terdapat masalah autokorelasi. Hasil uji heterokesdastisitas menunjukkan bahwa titik-titik pada scaterplot menyebar dan tidak terbentuk pola tertentu yang beraturan sehingga dapat disimpulkan bahwa dalam model regersi tidak terhadap masalah heterokesdastisitas. 


\section{Uji Hipotesis}

1). Koefisien Determinasi (Adjusted $R^{2}$ )

Hasil uji koefisien determinasi dapat dilihat pada yabel berikut ini:

Tabel 2 Koefisien Determinasi

\begin{tabular}{|l|c|r|c|c|c|}
\hline $\begin{array}{l}\text { Mode } \\
1\end{array}$ & $\mathrm{R}$ & $\mathrm{R}$ Square & $\begin{array}{c}\text { Adjusted R } \\
\text { Square }\end{array}$ & $\begin{array}{c}\text { Std. Error of } \\
\text { the Estimate }\end{array}$ & $\begin{array}{c}\text { Durbin- } \\
\text { Watson }\end{array}$ \\
\hline 1 & $.375^{\mathrm{a}}$ & .140 & .118 & .01936 & 1.504 \\
\hline
\end{tabular}
a. Predictors: (Constant), LEV, CR, ALTA, CASH, HUTA
b. Dependent Variable: ROA

Hasil uji regresi menunjukan nilai adjusted $R^{2}$ sebesar 0,118 atau $11.8 \%$. Pengujian koefisien determinasi menunjukan bahwa $11,8 \%$ perubahan profitabilitas BPR Konvesional di wilayah Kabupaten Ngawi, Magetan, Ponorogo serta Kabupaten dan Kota Madiun dipengaruhi oleh komponen modal kerja perusahaan. Sedangkan 88,2 \% dipengaruhi oleh faktor lain diluar model penelitian.

2) Nilai $F$

Hasil uji nilai F regresi dapat dilihat pada yabel berikut ini:

\section{Tabel 3. Nilai F}

\begin{tabular}{|c|c|c|c|c|c|c|}
\hline \multicolumn{7}{|c|}{ ANOVA ${ }^{b}$} \\
\hline & & $\begin{array}{c}\text { Sum of } \\
\text { Squares }\end{array}$ & df & Mean Square & $\mathrm{F}$ & Sig. \\
\hline \multirow[t]{3}{*}{1} & Regression & .012 & 5 & \multirow{3}{*}{$\begin{array}{l}.002 \\
.000\end{array}$} & \multirow[t]{3}{*}{6.369} & \multirow[t]{3}{*}{$.000^{=}$} \\
\hline & Residual & .073 & 195 & & & \\
\hline & Total & .085 & 200 & & & \\
\hline
\end{tabular}

Nilai F menunjukan angka sebesar 6.369 dengan nilai p 0.000. Uji ini memberikan hasil yang signifikan. Komponen rasio manajemen modal kerja perusahaan yang terdiri dari rasio aktiva lancar/total aktiva, rasio hutang lancar/total aktiva, current ratio, rasio kas dan rasio hutang berpengaruh secara simultan terhadap profitabilitas BPR Konvesional Kabupaten Ngawi, Magetan, Ponorogo serta Kabupaten dan Kota Madiun.

3) Nilai $t$

Hasil uji nilai t regresi dapat dilihat pada yabel berikut ini:

Tabel 4. Nilai $\mathrm{t}$

\begin{tabular}{|c|c|c|c|c|c|c|c|c|}
\hline \multicolumn{9}{|c|}{ Coefficients ${ }^{s}$} \\
\hline \multirow{2}{*}{\multicolumn{2}{|c|}{ Model }} & \multicolumn{2}{|c|}{ Unstandardized Coefficients } & \multirow{2}{*}{$\begin{array}{c}\begin{array}{c}\text { Standardized } \\
\text { Coefficients }\end{array} \\
\text { Beta }\end{array}$} & \multirow[b]{2}{*}{$t$} & \multirow[b]{2}{*}{ Siq. } & \multicolumn{2}{|c|}{ Collinearity Statistics } \\
\hline & & $B$ & Std. Error & & & & Tolerance & VIF \\
\hline \multirow[t]{6}{*}{1} & (Constant) & .066 & .010 & & 6.431 & .000 & & \\
\hline & ALTA & -.042 & .013 & -.277 & -3.314 & .001 & .631 & 1.585 \\
\hline & HLTA & -.010 & .010 & -.091 & -.972 & .332 & .502 & 1.991 \\
\hline & $\mathrm{CR}$ & -.005 & .002 & -.226 & -2.342 & .020 & .474 & 2.109 \\
\hline & $\mathrm{CASH}$ & -.516 & .206 & -.207 & -2.505 & .013 & .646 & 1.548 \\
\hline & LEV & -.018 & .010 & -.139 & -1.738 & .084 & .691 & 1.446 \\
\hline
\end{tabular}

a. Dependent Variable: ROA

Dari tabel di atas diketahui bahwa rasio manajemen modal kerja berupa rasio keuangan aktiva lancar/total aktiva berpengaruh negatif terhadap profitabilitas BPR. Hipotesis 1a diterima. 
Rasio manajemen modal kerja berupa rasio keuangan hutang lancar/total aktiva tidak berpengaruh terhadap profitabilitas BPR. Hipotesis $1 \mathrm{~b}$ tidak diterima. Rasio manajemen modal kerja berupa rasio keuangan current ratio berpengaruh negatif terhadap profitabilitas BPR. Hipotesis 1c diterima. Rasio manajemen modal kerja berupa rasio keuangan rasio kas berpengaruh negatif terhadap profitabilitas BPR. Hipotesis 1d diterima.Rasio manajemen modal kerja berupa rasio keuangan rasio hutang berpengaruh negatif terhadap profitabilitas BPR. Hipotesis 1e diterima. Secara keseluruhan peneliti menyimpulkan bahwa terdapat pengaruh manajemen modal kerja berpengaruh terhadap profitabilitas BPR di Madiun, Magetan, Ngawi dan Ponorogo.

Hasil penelitian menunjukan bahwa banyak rasio komponen modal kerja perusahaan yang berpengaruh negatif terhadap profitabilitas BPR di Madiun, Magetan, Ngawi dan Ponorogo. Hal ini menujukkan pola manajemen modal kerja BPR di Madiun, Magetan, Ngawi dan Ponorogo yang belum optimal.

\section{KESIMPULAN DAN SARAN}

Berdasarkan pada analisis data yang telah dilakukan dapat disimpulkan bahwa: 1) Pengujian koefisien determinasi menunjukan bahwa 11,8\% perubahan profitabilitas BPR Konvesional di wilayah Kabupaten Ngawi, Magetan, Ponorogo serta Kabupaten dan Kota Madiun dipengaruhi oleh komponen modal kerja perusahaan. Sedangkan 88,2 \% dipengaruhi oleh faktor lain diluar model penelitian. 2) Komponen rasio manajemen modal kerja perusahaan yang terdiri dari rasio aktiva lancar/total aktiva, rasio hutang lancar/total aktiva, current ratio, rasio kas dan rasio hutang berpengaruh secara simultan terhadap profitabilitas BPR Konvesional Kabupaten Ngawi, Magetan, Ponorogo serta Kabupaten dan Kota Madiun. 3) Rasio manajemen modal kerja berupa rasio keuangan aktiva lancar/total aktiva berpengaruh negatif terhadap profitabilitas BPR. 4) Rasio manajemen modal kerja berupa rasio keuangan hutang lancar/total aktiva tidak berpengaruh terhadap profitabilitas BPR. 5) Rasio manajemen modal kerja berupa rasio keuangan current ratio berpengaruh negatif terhadap profitabilitas BPR. 6) Rasio manajemen modal kerja berupa rasio keuangan rasio kas berpengaruh negatif terhadap profitabilitas BPR. 7) Rasio manajemen modal kerja berupa rasio keuangan rasio hutang berpengaruh negatif terhadap profitabilitas BPR.

Hal yang menjadi keterbatasan dalam penelitian ini adalah penelitian ini belum dapat mengungkapkan titik optimal pengelolaan modal kerja BPR Konvesional Kabupaten Ngawi, Magetan, Ponorogo serta Kabupaten dan Kota Madiun. Penelitian selanjutnya dapat dikembangkan dengan mengambil salah satu variabel komponen modal kerja perusahaan untuk kemudian mengcari titik optimal nilai keuangan yang dapat memberikan dampak yang positif terhadap profitabilitas BPR Konvesional Kabupaten Ngawi, Magetan, Ponorogo serta Kabupaten dan Kota Madiun.

\section{DAFTAR PUSTAKA}

Dong, Huynh Phuong dan Jyh-tay Su. The Relationship between Working capital Management and Profitability: A Vietnam Case. International Research Journal of Finance and Economics. Issue 49 
Falope, Olufemi dan Olubanje T. Ajilore. 2009. Working capital Management and Corporate Profitability: Evidance from Panel Data Analysis of Selected Quoted Companies at Nigeria. Research Journal of Business Management. Vol.3. Pp.73-84.

Ghozali, Imam. 2005. Analisis Multivariat dengan Program SPSS. Badan Penerbit Universitas Diponegoro: Semarang.

Hamdan, Umar dan Andi Wijaya. 2006. Analisis Komparatif Resiko Keuangan Bank Perkreditan Rakyat (BPR) Konvensional Dan BPR Syariah. Jurnal Manajemen dan Bisnis Sriwijaya, Vol.4, No.7.

Harahap, Rudi Dogar. 2010. Manajemen Likuiditas Perbankan Syariah. Asbanda Human Resource Development Center (AHRDC).

Herri; Tafdil Husni; Syahrial S; Suhairi; Edi Herman; dan Ma'ruf. 2008. Studi Peningkatan peran Bank Perkreditan Rakyat (BPR) dalam Pembiayaan Usaha Mikro Kecil (UMK) di Sumatera Barat. Center for Banking Research, Universitas Andalas.

Islamiyah, Azizatul. 2010. Analisis Manajemen Kredit untuk Menurunkan Terjadinya Kredit Bermasalah (Studi pada PT BPR Gunung Ringgit Malang). Skripsi Universitas Islam Negeri Maulana Malik Ibrahim Malang.

Jikrillah, Sufi. 2010. Pemetaan Profil Bank Perkreditan Rakyat Di Kabupaten Hulu Sungai Utara. Jurnal Manajemen dan Akuntansi. Vol. 11, No.1

Kaselaran, Preisy Valentina. 2013. Analisis Pengakuan dan Pengukuran Pendapatan Pada PT Bank BPR Millenia Berdasarkan PSAK. No.23. Jurnal EMBA, Vol. 1, No.3.

Kumara, Rian. 2009. Analisis Uji Beda Kinerja BPR YangMengikuti Linkage Program Dengan BPR Yang Tidak Mengikuti Linkage Program. Paper FE Universitas Gunadarma.

Maharani, Putri Oceana dan I Wayan Ramanthara. 2014. Pengaruh Efektivitas Struktur Pengendalian Intern Terhadap Kinerja Perkreditan Pada Bank Perkreditan Rakyat Di Kota Denpasar. E-Jurnal Akuntansi Universitas Udayana 6.1 Hal. 95-104

Mohamad, Nor Edi Azhar Binti dan Noriza Binti Mohd Saad. 2010. "Working capital Management: The Effect of Market Valuation and Profitability in Malaysia". Intemational Joumal of Business and Management. Vol. 5, No. 11

Nazir, Mian Sajid dan Talat Afza. 2009. Impact of Aggressive Working Capital Management Policy on Firms' Profitability. The IUP Journal of Applied Finance. Vol. 15, No. 8.

Qayyum, Abdul, Abdul Rahemen, Talat Afza, dan Mahmood Ahmed Bodla. 2010. Sectorwise Analysis of Working Capital Management and Firm Performance in Manufacturing Sector of Pakistan. Interdisciplinary Journal of Contemporary Research in Business. Vol.2. No.7

Sukma, Yoli Lara. 2013. Pengaruh Dana Pihak Ketiga, Kecukupan Modal Dan Risiko Kredit Terhadap Profitabilitas (Perusahaan Perbankan yang Terdaftar di BEI). Skripsi Universitas Negeri Padang. 
Sur, Debasish dan Kaushik Chakraborty. 2011. Evaluating Relationship ofWorking Capital and Profitability:A Study of Select Multinational Companies in the Indian Pharmaceutical Sector. The IUP Journal of Management Research, Vol. X, No. 2, 2011.

Septianto, Hendi dan Tatik Widiharih. 2010. Analisis Efisiensi Bank Perkreditan Rakyat Di Kota Semarang Dengan Pendekatan Data Envolepment Analysis. Media Statistika, Vol. 3, No. 1, Juni 2010: 41-48.

Wijaya, Anggita Langgeng dan Yulin Suswandari. 2014. Analisis Perbedaan Tingkat Likuiditas BPR Konvensional Dan BPR Syariah Guna Mengetahui Tingkat Kesehatan Keuangan Bank Perkreditan Rakyat (Studi Pada BPR Di Kabupaten Magetan Dan Ponorogo). Laporan Penelitian Dosen Pemula. IKIP PGRI MADIUN. 